Published in final edited form as:

Prog Mol Biol Transl Sci. 2011 ; 101: 1-21. doi:10.1016/B978-0-12-387685-0.00001-9.

\title{
Introduction-Epiphanies in Epigenetics
}

\author{
Xiaodong Cheng ${ }^{*}$ and Robert M. Blumenthal ${ }^{\dagger, \ddagger}$ \\ *Department of Biochemistry, Emory University School of Medicine, Atlanta, Georgia, USA \\ tDepartment of Medical Microbiology \& Immunology, University of Toledo Health Science \\ Campus, Toledo, Ohio, USA \\ ‡Program in Bioinformatics \& Proteomics/Genomics, University of Toledo Health Science \\ Campus, Toledo, Ohio, USA
}

\section{Abstract}

The combinatorial pattern of DNA and histone modifications and their associated histone variants constitute an epigenetic code that shapes gene expression patterns by increasing or decreasing the transcriptional potential of genomic domains. The epigenetic coding status, at any given chromosomal location, is subject to modulation by noncoding RNAs and remodeling complexes. DNA methylation is associated with histone modifications, particularly the absence of histone $\mathrm{H} 3$ lysine 4 methylation (H3K4me0) and the presence of histone $\mathrm{H} 3$ lysine 9 methylation (H3K9m). We briefly discuss four protein domains (ADD, CXXC, MBD, and SRA), and the functional implications of their architecture in linking histone methylation to that of DNA in mammalian cells. We also consider the domain structure of the DNA methyltransferase DNMT1, its accessory protein UHRF1, and their associated proteins. Finally, we discuss a mechanism by which methylation of DNA and of histones may be coordinately maintained during mitotic cell division, allowing for the transmission of parental methylation patterns to newly replicated chromatin.

\section{What is an Epigenetic Code?}

All cells face the problem of controlling the amounts and timing of expression of their various genes. In some cases, this control involves nonpermanent but relatively long-term and heritable modifications to the chromatin. Such modifications, that do not change the DNA sequence, are referred to as "epigenetic." The resulting epigenetic effects maintain the various patterns of gene expression in different cell types. ${ }^{1}$ Epigenetic modifications include DNA methylation and posttranslational histone modifications. Nucleosomes consist of approximately $146 \mathrm{bp}$ of DNA wrapped approximately 1.8 times around a histone octamer that is evolutionarily conserved. ${ }^{2}$ The combinatorial pattern of DNA and histone modifications constitutes an epigenetic code that shapes transcriptional patterns (Fig. 1A). The coding modification is "written" by sequence- and site-specific enzymes, and "interpreted" by effector molecules that mediate the assembly of higher-order chromatin structures involving remodeling complexes, histone variants, and noncoding RNAs (ncRNAs). ${ }^{12}$ 


\section{A. DNA Methylation}

In mammals and other vertebrates, DNA methylation occurs at the C5 position of cytosine, resulting in 5-methylcytosine (5mC), mostly within CpG dinucleotides (Fig. 1B). The Dnmt enzymes use a conserved mechanism ${ }^{13}$ that has been studied best in the bacterial $5 \mathrm{mC}$ MTase M.HhaI. ${ }^{14-18}$ Briefly, this mechanism involves MTase binding to the DNA, eversion of the target nucleotide so that it projects out of the double helix (base flipping), covalent attack of a conserved Cys nucleophile on cytosine C6, transfer of the methyl group from $S$ adenosyl-1-methionine (AdoMet) to the activated cytosine $\mathrm{C} 5$, and the various release steps.

\section{B. DNA Hydroxymethylation}

5-Hydroxymethylcytosine $(5 \mathrm{hmC})$ has long been noted in bacterial phage DNA. ${ }^{19-23}$ Its presence in mammalian cells ${ }^{24}$ was originally believed to be a byproduct of oxidative DNA damage. ${ }^{25}$ Recently, Kriaucionis and Heintz found that significant fractions ( 40\%) of cytosine nucleotides correspond to $5 \mathrm{hmC}$, the amount of which inversely correlates with $5 \mathrm{mC}$ and nuclear heterochromatin, in isolated and relatively homogenous populations of Purkinje and granule neuronal nuclei of adult mouse brains. ${ }^{26}$ Even more fascinating, a conserved mammalian-specific family of TET (ten-eleven translocation) proteins was identified that converts $5 \mathrm{mC}$ to $5 \mathrm{hmC}$ (Fig. 1B). ${ }^{10}$ One of these proteins, TET1, is fused to the MLL protein in a subset of acute myeloid leukemia patients. Overproduction of TET1 in human cells led to the appearance of $5 \mathrm{hmC}$. A concomitant reduction in DNA $5 \mathrm{mC}$ suggests that $5 \mathrm{hmC}$ results from enzymatic oxidation of $5 \mathrm{mC}$. $5 \mathrm{hmC}$ was also detected in ES cells, and its amount decreased with RNAi knockdown of TET1. The surprising finding of a 5mC oxidation pathway raises numerous questions, such as whether oxidation of $5 \mathrm{mC}$ is an important epigenetic modification. $5 \mathrm{hmC}$ could be an end product, or an intermediate in active DNA demethylation, as supported by the existence of a $5 \mathrm{hmC}$ DNA excision repair glycosylase ${ }^{27}$ It is intriguing that the bacterial $5 \mathrm{mC}$ MTase M.HhaI can promote the reverse reaction in vitro - the removal of formaldehyde from $5 \mathrm{hmC}$ to yield the unmodified cytosine $^{11}$ (Fig. 1C). New lines of research will likely be catalyzed by the presence of $5 \mathrm{hmC}$ in mammalian DNA.

\section{Histone Posttranslational Modifications}

Histones are subject to a multitude of posttranslational modifications, including acetylation, methylation, ubiquitination and sumoylation of lysines, and methylation of arginines. ${ }^{28}$ There is extensive crosstalk among histone modifications. ${ }^{29}$ As a result, different histone markings often have nonadditive effects. Structural and biochemical characterization of more of the players in histone modification are beginning to clarify the underlying mechanisms of crosstalk, and the interplay with other pathways, such as chromatin remodeling and DNA methylation and repair. ${ }^{30-33}$ Mechanistically, crosstalk occurs when one or more binding modules and catalytic domains reside in the same complex or polypeptide, allowing coordination of different activities. Crosstalk can occur prior to catalysis, in which case the recognition of one mark (or its absence) can serve to recruit an enzyme to its substrate in the generation or removal of a second mark. For example, phosphorylation of $\mathrm{H} 3$ serine 10 by Ipl1/aurora kinase interferes with methylation of $\mathrm{H} 3$ lysine 9 by SUV39H1, whereas acetylation of lysine 9 or lysine 14 enhances serine 10 
phosphorylation by Ipl1/aurora kinase. ${ }^{34}$ Ubiquitination of lysine 123 of histone H2B by

Rad6 regulates methylation of $\mathrm{H} 3$ lysines $4^{35}$ and 79 in Saccharomyces cerevisiae. ${ }^{36,37}$ PHF8 and KIAA1718 harbor two domains in their respective N-terminal halves: a PHD domain that binds trimethylated histone $\mathrm{H} 3$ lysine 4 (H3K4me3; a modification associated with transcriptional activation), and their linked Jumonji domains that remove methyl marks associated with transcriptional repression (di- and monomethylated histone $\mathrm{H} 3$ lysine 9, H3K9me2/1) via PHF8, ${ }^{38-41} \mathrm{H} 3 \mathrm{~K} 27 \mathrm{me} 2 / 1$ via KIAA1718, ${ }^{38,42,43}$ or H4K20me1 via PHF8. ${ }^{44,45}$

\section{Remodeling Complexes}

In eukarya, the packaging of DNA into chromatin provides a barrier that limits access to the genome. Condensed chromatin is refractory to processes acting on DNA, including transcription, replication, and repair. ${ }^{46,47}$ ATP-dependent chromatin-remodeling machinery can overcome this barrier-or strengthen it in silencing processes—by sliding or displacing nucleosomes and by altering their histone content. ${ }^{48}$

The modifications that constitute the histone code show significant interplay with the ATPdependent chromatin-remodeling machinery. The PHD finger of a component of the nucleosome remodeling factor (NURF) complex binds H3K4me3 ${ }^{49,50}$ INO80 and SWR1 chromatin-remodeling complexes are recruited through $\mathrm{H} 2 \mathrm{~A}$ phosphoryation at serine $129,{ }^{51}$ and SWI/SNF associates with acetylated histones via bromodomains. ${ }^{52-54}$ It is unclear to what extent histone code modifications and their binding modules serve as adaptors for the chromatin-remodeling machinery, and to what extent they regulate chromatin structure directly.

\section{E. Histone Variants}

The $\mathrm{H} 3$ variants (H3.1, 3.2, and 3.3) differ at just five positions. ${ }^{55,56}$ Importantly, the Nterminal 31 residues are identical, so there is no difference in the immediate contexts of $\mathrm{K} 4$ and $\mathrm{K} 9$; but other residues in the core histones affect $\mathrm{H} 3$ methylation-at least of K4. ${ }^{57}$ Even before incorporation into nucleosomes, some methylation at $\mathrm{H} 3 \mathrm{~K} 9$ has been reported $^{58}$; and this methylation is substantially more abundant on $\mathrm{H} 3.1$ than on $\mathrm{H} 3.3$ (which may only play a role in gametogenesis ${ }^{59}$ ).

\section{F. Noncoding RNAs (Including lincRNAs Like HOTAIR)}

ncRNAs are transcribed from DNA but are not translated into proteins. Many are functional, and are involved in the processing and regulation of other RNAs. Small ncRNAs, such as microRNAs (miRNAs) and short-interfering RNAs (siRNAs that cause RNA interference RNAi), are involved in the regulation of target mRNAs and chromatin. The ncRNAs can increase or decrease transcription, inhibit translation, or guide methylation. ${ }^{60-63}$ Longer ncRNAs (typically $>200 \mathrm{nt}$ ) have also been implicated in gene regulation ${ }^{64,65}$ and have roles in epigenetic processes. ${ }^{66}$ Some of these roles have been known for some time (e.g., Xchromosome inactivation ${ }^{67-70}$ and gene imprinting ${ }^{71-74}$ ). Further, long ncRNAs are components of histone-modifying complexes. The male-specific lethal (MSL) complex, responsible for dosage compensation in Drosophila, is an example of a class of complexes with five protein subunits (including a histone acetyltransferase, MOF) and one of the two 
ncRNAs, RNA on the X1 and 2 (rox 1 and rox 2$).{ }^{75}$ HOTAIR, a long ncRNA, serves as a scaffold for at least two distinct histone modification complexes. ${ }^{76}$ A $5^{\prime}$ domain of HOTAIR binds polycomb repressive complex 2 (PRC2) for histone H3 lysine 27

methylation, whereas a $3^{\prime}$ domain of HOTAIR binds the LSD1/CoREST/REST complex for coupled lysine 4 demethylation.

\section{Inheritance}

It is well accepted that DNA methylation patterns are replicated in a semiconservative fashion during cell division, via mechanisms discussed below (and in subsequent chapters). However, one of the fundamental unresolved questions is how, and indeed whether, histone modifications are similarly "inherited." Recent work has shed light on this question. Through a combination of kinetic isotope labeling and mass spectroscopy studies, $\mathrm{Xu}$ et al. showed that histone $\mathrm{H} 3.1-\mathrm{H} 4$ tetramers remain intact and are partitioned evenly during DNA replication-dependent chromatin assembly. ${ }^{77}$ Considering that the well-studied lysine methylation events reside on histone $\mathrm{H} 3$ (K4, K9, K27, K36, K79) or H4 (K20), this result suggests a model in which histone methylation patterns may be copied onto newly deposited tetramers from neighboring parental nucleosomes. Indeed, many of the SET domain histone methyltransferases contain intrinsic or associated "reader" domains that recognize the same mark that they generate, theoretically allowing the copying of these marks from old to new nucleosomes. For example, G9a/GLP catalyzes formation of H3K9me1/2 and contains an ankyrin repeat domain that binds $\mathrm{H} 3 \mathrm{~K} 9 \mathrm{me} 1 / 2 .{ }^{78}$ Likewise, SUV39H1/2, the H3K9me3 writer interacts with HP1, the H3K9me3 reader. ${ }^{79}$ Similarly, yeast Clr4 methylates H3K9 and contains a chromodomain that binds $\mathrm{H} 3 \mathrm{~K} 9 \mathrm{me} 3 .{ }^{80}$ These observations suggest coordinated mechanisms of deposition and replicative transmission of repressive chromatin marks.

The identification of UHRF1 and its potential role in modulating the specificity of Dnmt1 for hemimethylated $\mathrm{CpG}$ sites (see Chapter by Jafar Sharif and Haruhiko Koseki) adds another layer to the mechanisms ensuring the faithful transmission of epigenetic information during DNA replication. Hemimethylated CpG sites, where only one DNA strand is methylated, are transiently generated during semiconservative DNA replication. Methylation patterns are faithfully preserved with somatic cell division by a "maintenance" methylation reaction. UHRF1 has the potential to interact with both hemimethylated CpGs (via the SRA domain) and H3K9me2/3 (via the Tudor domain), and is known to interact with a wide variety of epigenetic regulators including Dnmt1, ${ }^{81,82}$ the $\mathrm{H} 3 \mathrm{~K} 9 \mathrm{di}$ - and monomethyltransferase G9a, ${ }^{83}$ and a histone acetyltransferase Tip60. ${ }^{84}$ Thus it is possible that UHRF1 and the proteins in this larger complex play a more central role in coupling the transmission of DNA and histone (H3K9 in particular) methylation during mitotic cell division.

\section{Modularity of Epigenetic Modifiers}

One broad emerging theme is that a web of interactions tightly coordinates the modification of a segment of DNA and its associated histones, particularly histone H3. This section focuses on four protein domains (ADD, CXXC, MBD, and SRA) in characterizing the 
functional links between histone and DNA modification in mammalian cells. In particular, we consider here the relationship between DNA CpG methylation and histone $\mathrm{H} 3$ methylation on lysines 4 and 9. ${ }^{85-91}$ DNA methylation and histone lysine methylation are intimately connected with one another. ${ }^{85,87-89}$ In fact, genome-scale DNA methylation profiles suggest that DNA methylation is correlated with histone methylation patterns. ${ }^{86}$ Specifically, DNA methylation is associated with the absence of H3K4 methylation (H3K4me0) and the presence of $\mathrm{H} 3 \mathrm{~K} 9$ methylation; by comparison, it has little correlation with methylation of $\mathrm{H} 3 \mathrm{~K} 27 .{ }^{90}$ In vivo studies support a molecular link between the mechanisms that maintain DNA methylation and H3K9 methylation. Studies in Neuropora and Arabidopsis have shown a strict dependence of DNA methylation on the H3K9 methyltransferases Dim-5 and KRYPTONITE. ${ }^{92-94}$ Functional linkage of the mechanisms defining genomic patterns of DNA methylation, $\mathrm{H} 3 \mathrm{~K} 4$ methylation, and $\mathrm{H} 3 \mathrm{~K} 9$ methylation is underscored by the finding that treatment with a DNA methyltransferase inhibitor (5aza-2' -deoxycytidine or 5azadC) leads to depletion of DNA methylation, with concomitant loss of $\mathrm{H} 3 \mathrm{~K} 9$ methylation and increase in $\mathrm{H} 3 \mathrm{~K} 4$ methylation. ${ }^{95}$

\section{A. ADD Domains of Dnmt3L/Dnmt3a/Dnmt3b Link DNA Methylation to Unmethylated H3K4}

DNA methylation in mammals is coordinately established and maintained by two DNA methyltransferase families, the so-called de novo enzymes of the Dnmt 3 family and the "maintenance" methyltransferase Dnmt1. The Dnmt3 family includes two active de novo Dnmts, Dnmt3a and Dnmt3b, and one regulatory factor, Dnmt3-like protein (Dnmt3L; Fig. 2A). Dnmt3a and Dnmt3b have similar domain arrangements: both contain a variable region at the N-terminus, followed by a PWWP domain, an ADD (ATRX-Dnmt3-Dnmt3L) domain, and a C-terminal catalytic domain. The amino acid sequence of the Dnmt3L ADD domain is very similar to those of Dnmt3a and Dnmt3b (Fig. 2A). Dnmt3L associates in vivo not only with Dnmt3b and Dnmt3a2 (a shorter isoform of Dnmt3 $\mathrm{a}^{99}$ ) but also with the four core histones. ${ }^{100}$ Peptide interaction assays and cocrystallization of Dnmt3L with the amino tail of $\mathrm{H} 3$ showed that Dnmt3L specifically interacts with the amino terminus of histone H3, only when H3K4 is not modified (H3K4me0). ${ }^{100}$ These observations suggest that Dnmt3L acts as a sensor for $\mathrm{H} 3 \mathrm{~K} 4$ methylation, such that $\mathrm{H} 3 \mathrm{~K} 4 \mathrm{~m} 0$ is bound by Dnmt3L, that consequently promotes de novo DNA methylation by docking Dnmt3a to the nucleosome (Fig. 2B).

Histone-Dnmt3L-Dnmt3a-DNA interactions have recently been studied in the budding yeast $S$. cerevisiae, ${ }^{101}$ which has no detectible native DNA methylation ${ }^{102}$ and lacks Dnmt orthologs. Introduction of the murine methyltransferase Dnmt1 or Dnmt3a into yeast leads to detectible, but extremely low levels of DNA methylation. ${ }^{103}$ In contrast, a substantially higher level of de novo methylation could be achieved in yeast by coexpressing murine Dnmt3a and Dnmt3L. ${ }^{101}$ This induced DNA methylation was found preferentially in heterochromatic regions where $\mathrm{H} 3 \mathrm{~K} 4$ methylation is rare. When genes for components of the H3K4-methylating complex COMPASS/Set1 were disrupted in the context of Dnmt3a/ Dnmt3L overexpression, a greater level of genomic DNA methylation was observed. Deletions or targeted mutations in the ADD of Dnmt3L inhibited both global DNA methylation and the ability of Dnmt3L to associate with an $\mathrm{H} 3 \mathrm{~K} 4 \mathrm{me} 0$ peptide. These same Dnmt3L mutants failed to restore normal DNA methylation to a specific promoter when 
introduced into ES cells from Dnmt3L $\mathrm{L}^{-/-}$mice. ${ }^{101}$ That H3K4 methylation status plays an important role in establishing DNA methylation is further supported by studies with mammalian LSD1 and LSD2, two related lysine-specific demethylases whose substrates include mono- and dimethylated H3K4 (H3K4me1/2; Fig. 2B). LSD1 and LSD2 are essential for maintaining global DNA methylation, ${ }^{104}$ or establishing maternal DNA genomic imprints, ${ }^{105}$ respectively. Indeed, disruption of $L S D 1$ results in earlier embryonic lethality and a more severe hypomethylation defect than disruption of the Dnmt genes themselves. ${ }^{104}$

The above data suggest that perhaps Dnmt3L binds to H3K4me0 (via its ADD domain) and recruits Dnmt3a to regions of chromatin where H3K4 is unmethylated. Such a model could explain part of the puzzle of how DNA methylation patterns are established de novo during embryonic and germ cell development, when both Dnmt3a and Dnmt3L are expressed. ${ }^{106}$ However, while Dnmt3a and Dnmt3b expression occurs in somatic cells, Dnmt3L is expressed poorly if at all in differentiated cells. This raises the questions of how de novo DNA methylation is restricted in somatic cells, whether Dnmt3a and Dnmt3b alone are capable of discriminating H3K4 methylation status, and (if so) the structural basis for that discrimination. To this end, recent work by Jeong et al. showed that in nuclei from HCT116 human colon cancer cells (which do not express DNMT3L), almost all of the cellular DNMT3a and DNMT3b (but not DNMT1) were associated with nucleosomes. ${ }^{107}$ Chromatin binding of DNMT3a and DNMT3b required an intact nucleosomal structure, though no other chromatin factors (such as the HP1 or MBD proteins), suggesting that DNMT3a and DNMT3b themselves can interact directly with chromatin components in addition to DNA. Further, recent in vitro studies indicate that the ADD domains of Dnmt3a or Dnmt3b possess the same $\mathrm{H} 3$ tail binding specificity as that of Dnmt3L. ${ }^{108}$ Indeed, a structure of the Dnmt3a ADD domain in complex with an amino-terminal tail peptide from histone $\mathrm{H} 3$ indicates that the ADD domain is sufficient to recognize H3K4me0. ${ }^{109}$

\section{B. The CXXC Domain Links H3K4 Methylation to Unmethylated CpGs}

In humans, there are at least eight histone lysine methyltransferases that act on H3K4. These include products of the mixed lineage leukemia $(M L L)$ genes, MLL1 through 5, hSET1a, hSET1b, and ASH1. MLL1/SET1-associated methyltransferase activity appears to be functional only in the context of multiprotein complexes; characterization of these reveals distinct multiprotein complexes for each of the eight, though with several shared components. ${ }^{110}$ The MLL family plays an important role in embryonic development and is necessary for methylation of $\mathrm{H} 3 \mathrm{~K} 4$ at a subset of genes in the human and mouse genomes, particularly the HOX gene clusters. ${ }^{111}$ Translocations involving $M L L$ genes are involved in the etiology of myeloid and lymphoid leukemias. Considering the aforementioned inverse relationship between $\mathrm{H} 3 \mathrm{~K} 4$ methylation and DNA methylation, it is interesting that disruption of the MLL1 gene in mice results in loss of both $\mathrm{H} 3 \mathrm{~K} 4$ methylation and de novo DNA methylation at some Hox gene promoters, ${ }^{112,113}$ suggesting that MLLs directly or indirectly (through H3K4 methylation) prevent DNA methylation or perhaps stabilize unmethylated DNA. In fact, MLL proteins contain CXXC, an evolutionarily conserved domain that mediates selective binding to unmethylated CpGs (Fig. 3A). ${ }^{14-116}$ This 
interaction has now been confirmed by a solution structure of an MLL1-CXXC domain complexed with unmethylated DNA. ${ }^{117}$

The Set1 H3K4 methyltransferases also appear to interact with unmethylated DNA, although in this case it is via an accessory protein, as with Dnmt3a/Dnmt3L (discussed above). Set1 lacks a CXXC domain, but interacts directly with a protein that contains onethe CXXC finger protein 1 (Cfp1) ${ }^{118-120}$ (Fig. 3A). High-throughput sequencing of Cfp1bound chromatin revealed a notable concordance between $\mathrm{H} 3 \mathrm{~K} 4 \mathrm{me} 3$ and $\mathrm{Cfp} 1$ at unmethylated $\mathrm{CpG}$ islands, in the mouse brain. ${ }^{121}$ At loci that exhibit allele-specific DNA methylation (e.g., imprinted loci, Xist gene), Cfp1 bound specifically to the unmethylated allele. Depletion of Cfp1 resulted in a marked reduction in $\mathrm{H} 3 \mathrm{~K} 4 \mathrm{me} 3$ genome wide. The targeting of $\mathrm{Cfp} 1$ to $\mathrm{CpG}$ islands was independent of promoter activity as the insertion of an unmethylated CpG-dense construct into the genome of ES cells was sufficient to nucleate Cfp1 binding and H3K4me3. This suggests that unmethylated CpGs recruit Cfp1, and the associated methyltransferase Set1 then creates new H3K4me3 marks on the local chromatin.

Like the histone H3K4 methyltransferases of the MLL/SET1 family, the Jumonji domaincontaining histone demethylase JHDM1a (known as KDM2A) also has a CXXC domain ${ }^{122}$ (Fig. 3A). Recent work indicates that, like Cfp1, JHDM1 is recruited to unmethylated CpG islands on a genome-wide scale, and that this is dependent on the CXXC domain. ${ }^{123}$ The localization to $\mathrm{CpG}$ islands was independent of promoter activity and gene expression levels, and correlated with the selective depletion of $\mathrm{H} 3 \mathrm{~K} 36 \mathrm{me} 1 / 2$ within the $\mathrm{CpG}$ island but not surrounding regions or the bodies of genes; knockdown of KDM2A resulted in the selective accumulation of $\mathrm{H} 3 \mathrm{~K} 36 \mathrm{me} 2$ in these regions. Consistent with a role for DNA methylation in determining the localization of CXXC proteins in Dnmt1-/- mice, KDM2A was mislocalized to pericentric heterochromatin. Further, the lack of methylation alone does not appear to be sufficient for KDM2A recruitment in vivo, as KDM2A does not localize to unmethylated non-CpG island promoters. Although in vitro studies suggest that $\mathrm{CXXC}$ domains can bind a single $\mathrm{CpG}$ site with micromolar affinity, both the Cfp1 and KDM2A studies suggest that the targeting of CXXC proteins in vivo is dependent on $\mathrm{CpG}$ density as well as methylation status. It is possible that these proteins oligomerize and form nucleoprotein filaments on CpG-dense DNA, in a manner similar to that described for Dnmt3a and Dnmt3L. ${ }^{124}$

CXXC domains are also found in DNMT1, the enzyme responsible for postreplication maintenance of 5-methyl-Cyt, ${ }^{125} \mathrm{MBD} 1$, themethyl-CpG-binding protein, ${ }^{126}$ and Tet1, a Jumonji-like 2-oxoglutarate- and $\mathrm{Fe}(\mathrm{II})$-dependent enzyme that catalyzes conversion of $5 \mathrm{mC}$ to $5 \mathrm{hmC}^{10}$ (Fig. 3A). Interestingly, a recurrent $\mathrm{t}^{19,20}(\mathrm{q} 22 ; \mathrm{q} 23)$ translocation has been described in acute myelogeous leukemias, and results in a fusion transcript that juxtaposes the first six exons of MLL(containing AT hook and CXXC) to the C-terminal one-third of TET1 thus "replacing" the TET1 CXXC with the MLL CXXC. ${ }^{127,128}$ Whether this leads to altered targeting of methyl hydroxylation remains to be determined.

\section{A Role for MBDs in the Linkage Between Histone Modification and DNA Methylation}

The methyl-CpG-binding domain (MBD) is present in a family of proteins conserved throughout the eukaryotic lineage. This domain, in some but not all cases, confers the ability 
to bind methylated CpGs. Mammals have five well-characterized members of this family, each with unique biological characteristics (reviewed in Ref. 129; Fig. 4A). Of particular interest are recent reports indicating that in zebrafish, MBD4 (containing both a $\mathrm{N}$-terminal MBD and a C-terminal thymine glycosylase domain, ${ }^{130}$ ) and the cytidine deaminase AID cooperate to demethylate DNA ${ }^{4}$ (see also Chapter byMary G. Goll and Marnie E. Halpern). Consistent with a role in DNA demethylation, erasure of DNA methylation in primordial germ cells is less efficient in AID-deficient animals, ${ }^{131}$ and AID is required to demethylate pluripotency genes during reprogramming of the somatic genome in ES cell fusions. ${ }^{132}$ It is noteworthy that phosphorylation of MBD4 enhances DNA demethylation. ${ }^{133}$

A particularly interesting observation, for the purposes of this review, is the fact that MBD1 forms a stable complex with SETDB1, ${ }^{134,135}$ an $\mathrm{H} 3 \mathrm{~K} 9$ me3 methyltransferase responsible for silencing of endogenous retroviruses ${ }^{136-138}$ as well as the Suv39h1/HP1 complex, ${ }^{139}$ a heterochromatin-specific H3K9me3 writer and reader. SETDB1 also contains an intrinsic putative MBD domain with two conserved DNA-interacting arginine residues (Fig. 4B) that make direct contact with DNA in the structures of the MBD domain from MBD1 ${ }^{140}$ and MeCP2. ${ }^{141}$ It remains to be seen whether the putative MBD domain of SETDB1 is similarly able to selectively bind methylated DNA. The intrinsic or associated coupling of a DNA methylation "reader" with H3K9me3 "writers" implies an interdependent mechanism for the propagation or maintenance of these marks.

As MBD1 contains two DNA-binding domains-an MBD domain (Fig. 4), which recognizes methylated $\mathrm{CpG}$, and a CXXC domain (Fig. 3), which binds unmethylated $\mathrm{CpG}$ - it is unclear whether these two domains function independently to facilitate the recruitment of MBD1 to repressive complexes or active complexes, or if they cooperate in some way. Recently, Clouaire et al. found that the MBD domain of MBD1 binds more efficiently to methylated DNA within a specific sequence context, and that a functional MBD domain is necessary and sufficient for recruitment of MBD1 to these loci, while DNA binding by the CXXC domain is largely dispensable. ${ }^{142}$

\section{UHRF1 Links Hemimethylated CpGs to Histone Modifications During Replication}

UHRF1 harbors five recognizable functional domains (Fig. 2A): a ubiquitin-like domain (UBL) at the N-terminus, followed by a tandem Tudor domain that binds H3K9me2/3, ${ }^{143,144}$ an ADD-like domain that binds the histone H3 tail, ${ }^{145,146}$ a SET- and RING-associated (SRA) domain that binds hemimethylated CpG-containing DNA, ${ }^{81,82,147-149}$ and a really interesting new gene (RING) domain at the C-terminus that may endow UHRF1 with E3 ubiquitin ligase activity for histones. ${ }^{145}$ As discussed above, Dnmt1 contains a CXXC domain (Fig. 3A) that binds unmethylated CpGs. ${ }^{125}$ The interaction with UHRF1 provides an SRA domain that recognizes hemimethylated CpGs, the substrate of Dnmt1. It is tempting to speculate that these two DNA-binding domains function synergically to maintain the fidelity of DNA methylation during replication, by preventing Dnmt1 from modifying unmethylated CpGs (through the masking of such sites by the CXXC domain) and directing methylation to newly synthesized hemimethylated $\mathrm{CpG}$ sites (via the SRA domain). Indeed, molecular modeling suggests that the Dnmt1 catalytic domain and UHRF1 SRA domain are very unlikely to bind simultaneously to the same 
hemimethylated CpG site. ${ }^{148}$ Somehow, the SRA domain must be displaced from the site to allow methylation by Dnmt1. ${ }^{150}$

We therefore suggest that the SRA-DNA interaction (through recognition of and flipping of the parental strand $5 \mathrm{mC}$ out of the helix ${ }^{147-149}$ ) serves as an anchor to keep UHRF1 at the hemimethylated $\mathrm{CpG}$ site where it then recruits Dnmt1 to methylate the opposing $\mathrm{CpG}$ in the daughter strand, which maintains the fidelity of DNA methylation.

\section{Acknowledgments}

The work in the authors' laboratories is currently supported by the U.S. National Institutes of Health (GM049245-17, GM068680-06, and GM092035-01 to X. C.) and the National Science Foundation (MCB-0964728 to R. M. B.). X. C. is a Georgia Research Alliance Eminent Scholar. This chapter is modified and updated from Ref. 91, with permission from American Chemical Society Publications.

\section{References}

1. Turner BM. Defining an epigenetic code. Nat Cell Biol. 2007; 9:2-6. [PubMed: 17199124]

2. Clapier CR, Chakravarthy S, Petosa C, Fernandez-Tornero C, Luger K, Muller CW. Structure of the Drosophila nucleosome core particle highlights evolutionary constraints on the H2A-H2B histone dimer. Proteins. 2008; 71:1-7. [PubMed: 17957772]

3. Dulac C. Brain function and chromatin plasticity. Nature. 2010; 465:728-735. [PubMed: 20535202]

4. Rai K, Huggins IJ, James SR, Karpf AR, Jones DA, Cairns BR. DNA demethylation in zebrafish involves the coupling of a deaminase, a glycosylase, and gadd45. Cell. 2008; 135:1201-1212. [PubMed: 19109892]

5. Kress C, Thomassin H, Grange T. Active cytosine demethylation triggered by a nuclear receptor involves DNA strand breaks. Proc Natl Acad Sci USA. 2006; 103:11112-11117. [PubMed: 16840560]

6. Vairapandi M. Characterization of DNA demethylation in normal and cancerous cell lines and the regulatory role of cell cycle proteins in human DNA demethylase activity. J Cell Biochem. 2004; 91:572-583. [PubMed: 14755686]

7. Kangaspeska S, Stride B, Metivier R, Polycarpou-Schwarz M, Ibberson D, Carmouche RP, et al. Transient cyclical methylation of promoter DNA. Nature. 2008; 452:112-115. [PubMed: 18322535]

8. Metivier R, Gallais R, Tiffoche C, Le Peron C, Jurkowska RZ, Carmouche RP, et al. Cyclical DNA methylation of a transcriptionally active promoter. Nature. 2008; 452:45-50. [PubMed: 18322525]

9. Ooi SK, Bestor TH. The colorful history of active DNA demethylation. Cell. 2008; 133:1145-1148. [PubMed: 18585349]

10. Tahiliani M, Koh KP, Shen Y, Pastor WA, Bandukwala H, Brudno Y, et al. Conversion of 5methylcytosine to 5-hydroxymethylcytosine in mammalian DNA by the MLL fusion partner TET1. Science. 2009; 324:930-935. [PubMed: 19372391]

11. Liutkeviciute Z, Lukinavicius G, Masevicius V, Daujotyte D, Klimasauskas S. Cytosine-5methyltransferases add aldehydes to DNA. Nat Chem Biol. 2009; 5:400-402. [PubMed: 19430486]

12. Kouzarides T. Chromatin modifications and their function. Cell. 2007; 128:693-705. [PubMed: 17320507]

13. Cheng X, Roberts RJ. AdoMet-dependent methylation, DNA methyltransferases and base flipping. Nucleic Acids Res. 2001; 29:3784-3795. [PubMed: 11557810]

14. Klimasauskas S, Kumar S, Roberts RJ, Cheng X. HhaI methyltransferase flips its target base out of the DNA helix. Cell. 1994; 76:357-369. [PubMed: 8293469]

15. Sheikhnejad G, Brank A, Christman JK, Goddard A, Alvarez E, Ford H Jr, et al. Mechanism of inhibition of DNA (cytosine C5)-methyltransferases by oligodeoxyribonucleotides containing 5,6dihydro-5-azacytosine. J Mol Biol. 1999; 285:2021-2034. [PubMed: 9925782] 
16. Wu JC, Santi DV. Kinetic and catalytic mechanism of HhaI methyltransferase. J Biol Chem. 1987; 262:4778-4786. [PubMed: 3558369]

17. Youngblood B, Shieh FK, Buller F, Bullock T, Reich NO. S-adenosyl-1-methionine-dependent methyl transfer: observable precatalytic intermediates during DNA cytosine methylation. Biochemistry. 2007; 46:8766-8775. [PubMed: 17616174]

18. Zhang X, Bruice TC. The mechanism of M.HhaI DNA C5 cytosine methyltransferase enzyme: a quantum mechanics/molecular mechanics approach. Proc Natl Acad Sci USA. 2006; 103:61486153. [PubMed: 16606828]

19. Wyatt GR, Cohen SS. The bases of the nucleic acids of some bacterial and animal viruses: the occurrence of 5-hydroxymethylcytosine. Biochem J. 1953; 55:774-782. [PubMed: 13115372]

20. Wiberg JS. Amber mutants of bacteriophage T4 defective in deoxycytidine diphosphatase and deoxycytidine triphosphatase. On the role of 5-hydroxymethylcytosine in bacteriophage deoxyribonucleic acid. J Biol Chem. 1967; 242:5824-5589. [PubMed: 4319673]

21. Anisymova NI, Gabrilovich IM, Soshina NV, Cherenkevich SN. 5-Hydroxymethylcytosinecontaining Klebsiella bacteriophage. Biochim Biophys Acta. 1969; 190:225-227. [PubMed: 5822852]

22. Fleischman RA, Cambell JL, Richardson CC. Modification and restriction of T-even bacteriophages. In vitro degradation of deoxyribonucleic acid containing 5-hydroxymethylctosine. J Biol Chem. 1976; 251:1561-1570. [PubMed: 767337]

23. Warren RA. Modified bases in bacteriophage DNAs. Annu Rev Microbiol. 1980; 34:137-158. [PubMed: 7002022]

24. Penn NW, Suwalski R, O'Riley C, Bojanowski K, Yura R. The presence of 5hydroxymethylcytosine in animal deoxyribonucleic acid. Biochem J. 1972; 126:781-790. [PubMed: 4538516]

25. Castro GD, Diaz Gomez MI, Castro JA. 5-Methylcytosine attack by hydroxyl free radicals and during carbon tetrachloride promoted liver microsomal lipid peroxidation: structure of reaction products. Chem Biol Interact. 1996; 99:289-299. [PubMed: 8620576]

26. Kriaucionis S, Heintz N. The nuclear DNA base 5-hydroxymethylcytosine is present in Purkinje neurons and the brain. Science. 2009; 324:929-930. [PubMed: 19372393]

27. Cannon SV, Cummings A, Teebor GW. 5-Hydroxymethylcytosine DNA glycosylase activity in mammalian tissue. Biochem Biophys Res Commun. 1988; 151:1173-1179. [PubMed: 3355548]

28. Strahl BD, Allis CD. The language of covalent histone modifications. Nature. 2000; 403:41-45. [PubMed: 10638745]

29. Suganuma T, Workman JL. Crosstalk among histone modifications. Cell. 2008; 135:604-607. [PubMed: 19013272]

30. Hung T, Binda O, Champagne KS, Kuo AJ, Johnson K, Chang HY, et al. ING4 mediates crosstalk between histone $\mathrm{H} 3 \mathrm{~K} 4$ trimethylation and $\mathrm{H} 3$ acetylation to attenuate cellular transformation. Mol Cell. 2009; 33:248-256. [PubMed: 19187765]

31. Lee JS, Shukla A, Schneider J, Swanson SK, Washburn MP, Florens L, et al. Histone crosstalk between H2B monoubiquitination and H3 methylation mediated by COMPASS. Cell. 2007; 131:1084-1096. [PubMed: 18083099]

32. Adhvaryu KK, Selker EU. Protein phosphatase PP1 is required for normal DNA methylation in Neurospora. Genes Dev. 2008; 22:3391-3396. [PubMed: 19141471]

33. van Attikum H, Gasser SM. Crosstalk between histone modifications during the DNA damage response. Trends Cell Biol. 2009; 19:207-217. [PubMed: 19342239]

34. Rea S, Eisenhaber F, O'Carroll D, Strahl BD, Sun ZW, Schmid M, et al. Regulation of chromatin structure by site-specific histone H3 methyltransferases. Nature. 2000; 406:593-599. [PubMed: 10949293]

35. Sun ZW, Allis CD. Ubiquitination of histone $\mathrm{H} 2 \mathrm{~B}$ regulates $\mathrm{H} 3$ methylation and gene silencing in yeast. Nature. 2002; 418:104-108. [PubMed: 12077605]

36. Ng HH, Xu RM, Zhang Y, Struhl K. Ubiquitination of histone H2B by Rad6 is required for efficient Dot1-mediated methylation of histone H3 lysine 79. J Biol Chem. 2002; 277:3465534657. [PubMed: 12167634] 
37. Briggs SD, Xiao T, Sun ZW, Caldwell JA, Shabanowitz J, Hunt DF, et al. Gene silencing: transhistone regulatory pathway in chromatin. Nature. 2002; 418:498. [PubMed: 12152067]

38. Horton JR, Upadhyay AK, Qi HH, Zhang X, Shi Y, Cheng X. Enzymatic and structural insights for substrate specificity of a family of jumonji histone lysine demethylases. Nat Struct Mol Biol. 2010; 17:38-43. [PubMed: 20023638]

39. Fortschegger K, de Graaf P, Outchkourov NS, van Schaik FM, Timmers HT, Shiekhattar R. PHF8 targets histone methylation and RNA polymerase II to activate transcription. Mol Cell Biol. 2010; 30:3286-3298. [PubMed: 20421419]

40. Kleine-Kohlbrecher D, Christensen J, Vandamme J, Abarrategui I, Bak M, Tommerup N, et al. A functional link between the histone demethylase PHF8 and the transcription factor ZNF711 in Xlinked mental retardation. Mol Cell. 2010; 38:165-178. [PubMed: 20346720]

41. Feng W, Yonezawa M, Ye J, Jenuwein T, Grummt I. PHF8 activates transcription of rRNA genes through H3K4me3 binding and H3K9me1/2 demethylation. Nat Struct Mol Biol. 2010; 17:445450. [PubMed: 20208542]

42. Yokoyama A, Okuno Y, Chikanishi T, Hashiba W, Sekine H, Fujiki R, et al. KIAA1718 is a histone demethylase that erases repressive histone methyl marks. Genes Cells. 2010; 15:867-873. [PubMed: 20629981]

43. Huang C, Xiang Y, Wang Y, Li X, Xu L, Zhu Z, et al. Dual-specificity histone demethylase KIAA1718 (KDM7A) regulates neural differentiation through FGF4. Cell Res. 2010; 20:154-165. [PubMed: 20084082]

44. Liu W, Tanasa B, Tyurina OV, Zhou TY, Gassmann R, Liu WT, et al. PHF8 mediates histone H4 lysine 20 demethylation events involved in cell cycle progression. Nature. 2010; 466:508-512. [PubMed: 20622854]

45. Qi HH, Sarkissian M, Hu GQ, Wang Z, Bhattacharjee A, Gordon DB, et al. Histone H4K20/H3K9 demethylase PHF8 regulates zebrafish brain and craniofacial development. Nature. 2010; 466:503-507. [PubMed: 20622853]

46. Li B, Carey M, Workman JL. The role of chromatin during transcription. Cell. 2007; 128:707-719. [PubMed: 17320508]

47. Groth A, Corpet A, Cook AJ, Roche D, Bartek J, Lukas J, et al. Regulation of replication fork progression through histone supply and demand. Science. 2007; 318:1928-1931. [PubMed: 18096807]

48. Cairns BR. Chromatin remodeling: insights and intrigue from single-molecule studies. Nat Struct Mol Biol. 2007; 14:989-996. [PubMed: 17984961]

49. Li H, Ilin S, Wang W, Duncan EM, Wysocka J, Allis CD, et al. Molecular basis for site-specific read-out of histone H3K4me3 by the BPTF PHD finger of NURF. Nature. 2006; 442:91-95. [PubMed: 16728978]

50. Wysocka J, Swigut T, Xiao H, Milne TA, Kwon SY, Landry J, et al. A PHD finger of NURF couples histone H3 lysine 4 trimethylation with chromatin remodelling. Nature. 2006; 442:86-90. [PubMed: 16728976]

51. Downs JA, Allard S, Jobin-Robitaille O, Javaheri A, Auger A, Bouchard N, et al. Binding of chromatin-modifying activities to phosphorylated histone H2A at DNA damage sites. Mol Cell. 2004; 16:979-990. [PubMed: 15610740]

52. Hassan AH, Neely KE, Workman JL. Histone acetyltransferase complexes stabilize swi/snf binding to promoter nucleosomes. Cell. 2001; 104:817-827. [PubMed: 11290320]

53. Hassan AH, Prochasson P, Neely KE, Galasinski SC, Chandy M, Carrozza MJ, et al. Function and selectivity of bromodomains in anchoring chromatin-modifying complexes to promoter nucleosomes. Cell. 2002; 111:369-379. [PubMed: 12419247]

54. Syntichaki P, Topalidou I, Thireos G. The Gen5 bromodomain co-ordinates nucleosome remodelling. Nature. 2000; 404:414-417. [PubMed: 10746732]

55. Hake SB, Allis CD. Histone $\mathrm{H} 3$ variants and their potential role in indexing mammalian genomes: the "H3 barcode hypothesis". Proc Natl Acad Sci USA. 2006; 103:6428-6435. [PubMed: 16571659] 
56. Hake SB, Garcia BA, Duncan EM, Kauer M, Dellaire G, Shabanowitz J, et al. Expression patterns and post-translational modifications associated with mammalian histone $\mathrm{H} 3$ variants. J Biol Chem. 2006; 281:559-568. [PubMed: 16267050]

57. Nakanishi S, Sanderson BW, Delventhal KM, Bradford WD, Staehling-Hampton K, Shilatifard A. A comprehensive library of histone mutants identifies nucleosomal residues required for H3K4 methylation. Nat Struct Mol Biol. 2008; 15:881-888. [PubMed: 18622391]

58. Loyola A, Bonaldi T, Roche D, Imhof A, Almouzni G. PTMs on H3 variants before chromatin assembly potentiate their final epigenetic state. Mol Cell. 2006; 24:309-316. [PubMed: 17052464]

59. Hodl M, Basler K. Transcription in the absence of histone H3.3. Curr Biol. 2009; 19:1221-1226. [PubMed: 19523831]

60. Collins LJ, Chen XS. Ancestral RNA: the RNA biology of the eukaryotic ancestor. RNA Biol. 2009; 6:495-502. [PubMed: 19713749]

61. Collins LJ, Penny D. The RNA infrastructure: dark matter of the eukaryotic cell? Trends Genet. 2009; 25:120-128. [PubMed: 19171405]

62. Collins RE, Cheng X. Structural and biochemical advances in mammalian RNAi. J Cell Biochem. 2006; 99:1251-1266. [PubMed: 16927374]

63. Collins RE, Cheng X. Structural domains in RNAi. FEBS Lett. 2005; 579:5841-5849. [PubMed: 16107250]

64. Mercer TR, Dinger ME, Mattick JS. Long non-coding RNAs: insights into functions. Nat Rev Genet. 2009; 10:155-159. [PubMed: 19188922]

65. Mattick JS. The genetic signatures of noncoding RNAs. PLoS Genet. 2009; 5:e1000459. [PubMed: 19390609]

66. Kurokawa R, Rosenfeld MG, Glass CK. Transcriptional regulation through noncoding RNAs and epigenetic modifications. RNA Biol. 2009; 6:233-236. [PubMed: 19411842]

67. Chow J, Heard E. X inactivation and the complexities of silencing a sex chromosome. Curr Opin Cell Biol. 2009; 21:359-366. [PubMed: 19477626]

68. Lee JT. Lessons from X-chromosome inactivation: long ncRNA as guides and tethers to the epigenome. Genes Dev. 2009; 23:1831-1842. [PubMed: 19684108]

69. Tian D, Sun S, Lee JT. The long noncoding RNA, jpx, is a molecular switch for x chromosome inactivation. Cell. 2010; 143:390-403. [PubMed: 21029862]

70. Lee JT. The $X$ as model for RNA's niche in epigenomic regulation. Cold Spring Harb Perspect Biol. 2010; 2:a003749. [PubMed: 20739414]

71. Royo H, Cavaille J. Non-coding RNAs in imprinted gene clusters. Biol Cell. 2008; 100:149-166. [PubMed: 18271756]

72. Latos PA, Barlow DP. Regulation of imprinted expression by macro non-coding RNAs. RNA Biol. 2009; 6:100-106. [PubMed: 19229135]

73. Koerner MV, Pauler FM, Huang R, Barlow DP. The function of non-coding RNAs in genomic imprinting. Development. 2009; 136:1771-1783. [PubMed: 19429783]

74. Koerner MV, Barlow DP. Genomic imprinting — an epigenetic gene-regulatory model. Curr Opin Genet Dev. 2010; 20:164-170. [PubMed: 20153958]

75. Lucchesi JC. The structure-function link of compensated chromatin in Drosophila. Curr Opin Genet Dev. 2009; 19:550-556. [PubMed: 19880310]

76. Tsai MC, Manor O, Wan Y, Mosammaparast N, Wang JK, Lan F, et al. Long noncoding RNA as modular scaffold of histone modification complexes. Science. 2010; 329:689-693. [PubMed: 20616235]

77. Xu M, Long C, Chen X, Huang C, Chen S, Zhu B. Partitioning of histone H3-H4 tetramers during DNA replication-dependent chromatin assembly. Science. 2010; 328:94-98. [PubMed: 20360108]

78. Collins RE, Northrop JP, Horton JR, Lee DY, Zhang X, Stallcup MR, et al. The ankyrin repeats of G9a and GLP histone methyltransferases are mono- and dimethyllysine binding modules. Nat Struct Mol Biol. 2008; 15:245-250. [PubMed: 18264113]

79. Grewal SI, Jia S. Heterochromatin revisited. Nat Rev Genet. 2007; 8:35-46. [PubMed: 17173056] 
80. Zhang K, Mosch K, Fischle W, Grewal SI. Roles of the Clr4 methyltransferase complex in nucleation, spreading and maintenance of heterochromatin. Nat Struct Mol Biol. 2008; 15:381388. [PubMed: 18345014]

81. Bostick M, Kim JK, Esteve PO, Clark A, Pradhan S, Jacobsen SE. UHRF1 plays a role in maintaining DNA methylation in mammalian cells. Science. 2007; 317:1760-1764. [PubMed: 17673620]

82. Sharif J, Muto M, Takebayashi S, Suetake I, Iwamatsu A, Endo TA, et al. The SRA protein Np95 mediates epigenetic inheritance by recruiting Dnmt1 to methylated DNA. Nature. 2007; 450:908912. [PubMed: 17994007]

83. Kim JK, Esteve PO, Jacobsen SE, Pradhan S. UHRF1 binds G9a and participates in p21 transcriptional regulation in mammalian cells. Nucleic Acids Res. 2009; 37:493-505. [PubMed: 19056828]

84. Achour M, Fuhrmann G, Alhosin M, Ronde P, Chataigneau T, Mousli M, et al. UHRF1 recruits the histone acetyltransferase Tip60 and controls its expression and activity. Biochem Biophys Res Commun. 2009; 390:523-528. [PubMed: 19800870]

85. Bernstein BE, Meissner A, Lander ES. The mammalian epigenome. Cell. 2007; 128:669-681. [PubMed: 17320505]

86. Meissner A, Mikkelsen TS, Gu H, Wernig M, Hanna J, Sivachenko A, et al. Genome-scale DNA methylation maps of pluripotent and differentiated cells. Nature. 2008; 454:766-770. [PubMed: 18600261]

87. Fan S, Zhang MQ, Zhang X. Histone methylation marks play important roles in predicting the methylation status of CpG islands. Biochem Biophys Res Commun. 2008; 374:559-564. [PubMed: 18656446]

88. Cedar H, Bergman Y. Linking DNA methylation and histone modification: patterns and paradigms. Nat Rev Genet. 2009; 10:295-304. [PubMed: 19308066]

89. Dindot SV, Person R, Strivens M, Garcia R, Beaudet AL. Epigenetic profiling at mouse imprinted gene clusters reveals novel epigenetic and genetic features at differentially methylated regions. Genome Res. 2009; 19:1374-1383. [PubMed: 19542493]

90. Laurent L, Wong E, Li G, Huynh T, Tsirigos A, Ong CT, et al. Dynamic changes in the human methylome during differentiation. Genome Res. 2010; 20:320-331. [PubMed: 20133333]

91. Cheng X, Blumenthal RM. Coordinated chromatin control: structural and functional linkage of DNA and histone methylation. Biochemistry. 2010; 49:2999-3008. [PubMed: 20210320]

92. Tamaru H, Zhang X, McMillen D, Singh PB, Nakayama J, Grewal SI, et al. Trimethylated lysine 9 of histone H3 is a mark for DNA methylation in Neurospora crassa. Nat Genet. 2003; 34:75-79. [PubMed: 12679815]

93. Tamaru H, Selker EU. A histone H3 methyltransferase controls DNA methylation in Neurospora crassa. Nature. 2001; 414:277-283. [PubMed: 11713521]

94. Jackson JP, Lindroth AM, Cao X, Jacobsen SE. Control of CpNpG DNA methylation by the KRYPTONITE histone H3 methyltransferase. Nature. 2002; 416:556-560. [PubMed: 11898023]

95. Nguyen CT, Weisenberger DJ, Velicescu M, Gonzales FA, Lin JC, Liang G, et al. Histone H3lysine 9 methylation is associated with aberrant gene silencing in cancer cells and is rapidly reversed by 5-aza-20-deoxycytidine. Cancer Res. 2002; 62:6456-6461. [PubMed: 12438235]

96. Elsaesser SJ, Goldberg AD, Allis CD. New functions for an old variant: no substitute for histone H3.3. Curr Opin Genet Dev. 2010; 20:110-117. [PubMed: 20153629]

97. Goldberg AD, Banaszynski LA, Noh KM, Lewis PW, Elsaesser SJ, Stadler S, et al. Distinct factors control histone variant H3.3 localization at specific genomic regions. Cell. 2010; 140:678-691. [PubMed: 20211137]

98. Wong LH, McGhie JD, Sim M, Anderson MA, Ahn S, Hannan RD, et al. ATRX interacts with H3.3 in maintaining telomere structural integrity in pluripotent embryonic stem cells. Genome Res. 2010; 20:351-360. [PubMed: 20110566]

99. Chen T, Ueda Y, Xie S, Li E. A novel Dnmt3a isoform produced from an alternative promoter localizes to euchromatin and its expression correlates with active de novo methylation. J Biol Chem. 2002; 277:38746-38754. [PubMed: 12138111] 
100. Ooi SKT, Qiu C, Bernstein E, Li K, Jia D, Yang Z, et al. DNMT3L connects unmethylated lysine 4 of histone H3 to de novo methylation of DNA. Nature. 2007; 448:714-717. [PubMed: 17687327]

101. Hu JL, Zhou BO, Zhang RR, Zhang KL, Zhou JQ, Xu GL. The N-terminus of histone H3 is required for de novo DNA methylation in chromatin. Proc Natl Acad Sci USA. 2009; 106:22187-22192. [PubMed: 20018712]

102. Proffitt JH, Davie JR, Swinton D, Hattman S. 5-Methylcytosine is not detectable in Saccharomyces cerevisiae DNA. Mol Cell Biol. 1984; 4:985-988. [PubMed: 63744428]

103. Bulkowska U, Ishikawa T, Kurlandzka A, Trzcinska-Danielewicz J, Derlacz R, Fronk J. Expression of murine DNA methyltransferases Dnmt1 and Dnmt3a in the yeast Saccharomyces cerevisiae. Yeast. 2007; 24:871-882. [PubMed: 17640084]

104. Wang J, Hevi S, Kurash JK, Lei H, Gay F, Bajko J, et al. The lysine demethylase LSD1 (KDM1) is required for maintenance of global DNA methylation. Nat Genet. 2009; 41:125-129. [PubMed: 19098913]

105. Ciccone DN, Su H, Hevi S, Gay F, Lei H, Bajko J, et al. KDM1B is a histone H3K4 demethylase required to establish maternal genomic imprints. Nature. 2009; 461:359-360. [PubMed: 19759613]

106. Kato Y, Kaneda M, Hata K, Kumaki K, Hisano M, Kohara Y, et al. Role of the Dnmt3 family in de novo methylation of imprinted and repetitive sequences during male germ cell development in the mouse. Hum Mol Genet. 2007; 16:2272-2280. [PubMed: 17616512]

107. Jeong S, Liang G, Sharma S, Lin JC, Choi SH, Han H, et al. Selective anchoring of DNA methyltransferases 3A/3B to nucleosomes containing methylated DNA. Mol Cell Biol. 2009; 29:5366-5376. [PubMed: 19620278]

108. Zhang Y, Jurkowska R, Soeroes S, Rajavelu A, Dhayalan A, Bock I, et al. Chromatin methylation activity of Dnmt3a and Dnmt3a/3L is guided by interaction of the ADD domain with the histone H3 tail. Nucleic Acids Res. 2010; 38:4246-4253. [PubMed: 20223770]

109. Otani J, Nankumo T, Arita K, Inamoto S, Ariyoshi M, Shirakawa M. Structural basis for recognition of H3K4 methylation status by the DNA methyltransferase 3A ATRX-DNMT3DNMT3L domain. EMBO Rep. 2009; 10:1235-1241. [PubMed: 19834512]

110. Cosgrove MS, Patel A. Mixed lineage leukemia: a structure-function perspective of the MLL1 protein. FEBS J. 2010; 277:1832-1842. [PubMed: 20236310]

111. Ansari KI, Mandal SS. Mixed lineage leukemia: roles in gene expression, hormone signaling and mRNA processing. FEBS J. 2010; 277:1790-1804. [PubMed: 20236313]

112. Terranova R, Agherbi H, Boned A, Meresse S, Djabali M. Histone and DNA methylation defects at Hox genes in mice expressing a SET domain-truncated form of Mll. Proc Natl Acad Sci USA. 2006; 103:6629-6634. [PubMed: 16618927]

113. Milne TA, Briggs SD, Brock HW, Martin ME, Gibbs D, Allis CD, et al. MLL targets SET domain methyltransferase activity to Hox gene promoters. Mol Cell. 2002; 10:1107-1117. [PubMed: 12453418]

114. Birke M, Schreiner S, Garcia-Cuellar MP, Mahr K, Titgemeyer F, Slany RK. The MT domain of the proto-oncoprotein MLL binds to CpG-containing DNA and discriminates against methylation. Nucleic Acids Res. 2002; 30:958-965. [PubMed: 11842107]

115. Ayton PM, Chen EH, Cleary ML. Binding to nonmethylated CpG DNA is essential for target recognition, transactivation, and myeloid transformation by an MLL oncoprotein. Mol Cell Biol. 2004; 24:10470-10478. [PubMed: 15542854]

116. Allen MD, Grummitt CG, Hilcenko C, Min SY, Tonkin LM, Johnson CM, et al. Solution structure of the nonmethyl-CpG-binding CXXC domain of the leukaemia-associated MLL histone methyltransferase. EMBO J. 2006; 25:4503-4512. [PubMed: 16990798]

117. Cierpicki T, Risner LE, Grembecka J, Lukasik SM, Popovic R, Omonkowska M, et al. Structure of the MLL CXXC domain-DNA complex and its functional role in MLL-AF9 leukemia. Nat Struct Mol Biol. 2010; 17:62-68. [PubMed: 20010842]

118. Lee JH, Voo KS, Skalnik DG. Identification and characterization of the DNA binding domain of CpG-binding protein. J Biol Chem. 2001; 276:44669-44676. [PubMed: 11572867] 
119. Lee JH, Skalnik DG. CpG-binding protein (CXXC finger protein 1) is a component of the mammalian Set1 histone H3-Lys4 methyltransferase complex, the analogue of the yeast Set1/ COMPASS complex. J Biol Chem. 2005; 280:41725-41731. [PubMed: 16253997]

120. Lee JH, Tate CM, You JS, Skalnik DG. Identification and characterization of the human Set1B histone H3-Lys4 methyltransferase complex. J Biol Chem. 2007; 282:13419-13428. [PubMed: 17355966]

121. Thomson JP, Skene PJ, Selfridge J, Clouaire T, Guy J, Webb S, et al. CpG islands influence chromatin structure via the CpG-binding protein Cfp1. Nature. 2010; 464:1082-1086. [PubMed: 20393567]

122. Tsukada Y, Fang J, Erdjument-Bromage H, Warren ME, Borchers CH, Tempst P, et al. Histone demethylation by a family of JmjC domain-containing proteins. Nature. 2006; 439:811-816. [PubMed: 16362057]

123. Blackledge NP, Zhou JC, Tolstorukov MY, Farcas AM, Park PJ, Klose RJ. CpG islands recruit a histone H3 lysine 36 demethylase. Mol Cell. 2010; 38:179-190. [PubMed: 20417597]

124. Jurkowska RZ, Anspach N, Urbanke C, Jia D, Reinhardt R, Nellen W, et al. Formation of nucleoprotein filaments by mammalian DNA methyltransferase Dnmt3a in complex with regulator Dnmt3L. Nucleic Acids Res. 2008; 36:6656-6663. [PubMed: 18945701]

125. Pradhan M, Esteve PO, Chin HG, Samaranayke M, Kim GD, Pradhan S. CXXC domain of human DNMT1 is essential for enzymatic activity. Biochemistry. 2008; 47:10000-10009. [PubMed: 18754681]

126. Jorgensen HF, Ben-Porath I, Bird AP. Mbd1 is recruited to both methylated and nonmethylated CpGs via distinct DNA binding domains. Mol Cell Biol. 2004; 24:3387-3395. [PubMed: 15060159]

127. Ono R, Taki T, Taketani T, Taniwaki M, Kobayashi H, Hayashi Y. LCX, leukemia-associated protein with a CXXC domain, is fused to MLL in acute myeloid leukemia with trilineage dysplasia having t(10;11)(q22;q23). Cancer Res. 2002; 62:4075-4080. [PubMed: 12124344]

128. Lorsbach RB, Moore J, Mathew S, Raimondi SC, Mukatira ST, Downing JR. TET1, a member of a novel protein family, is fused to MLL in acute myeloid leukemia containing the $t(10 ; 11)$ (q22;q23). Leukemia. 2003; 17:637-641. [PubMed: 12646957]

129. Dhasarathy A, Wade PA. The MBD protein family-reading an epigenetic mark? Mutat Res. 2008; 647:39-43. [PubMed: 18692077]

130. Hendrich B, Hardeland U, Ng HH, Jiricny J, Bird A. The thymine glycosylase MBD4 can bind to the product of deamination at methylated CpG sites. Nature. 1999; 401:301-304. [PubMed: 10499592]

131. Popp C, Dean W, Feng S, Cokus SJ, Andrews S, Pellegrini M, et al. Genome-wide erasure of DNA methylation in mouse primordial germ cells is affected by AID deficiency. Nature. 2010; 463:1101-1105. [PubMed: 20098412]

132. Bhutani N, Brady JJ, Damian M, Sacco A, Corbel SY, Blau HM. Reprogramming towards pluripotency requires AID-dependent DNA demethylation. Nature. 2010; 463:1042-1047. [PubMed: 20027182]

133. Kim MS, Kondo T, Takada I, Youn MY, Yamamoto Y, Takahashi S, et al. DNA demethylation in hormone-induced transcriptional derepression. Nature. 2009; 461:1007-1012. [PubMed: 19829383]

134. Sarraf SA, Stancheva I. Methyl-CpG binding protein MBD1 couples histone H3 methylation at lysine 9 by SETDB1 to DNA replication and chromatin assembly. Mol Cell. 2004; 15:595-605. [PubMed: 15327775]

135. Lyst MJ, Nan X, Stancheva I. Regulation of MBD1-mediated transcriptional repression by SUMO and PIAS proteins. EMBO J. 2006; 25:5317-5328. [PubMed: 17066076]

136. Schultz DC, Ayyanathan K, Negorev D, Maul GG, Rauscher FJ 3rd. SETDB1: a novel KAP-1associated histone H3, lysine 9-specific methyltransferase that contributes to HP1-mediated silencing of euchromatic genes by KRAB zinc-finger proteins. Genes Dev. 2002; 16:919-932. [PubMed: 11959841] 
137. Rowe HM, Jakobsson J, Mesnard D, Rougemont J, Reynard S, Aktas T, et al. KAP1 controls endogenous retroviruses in embryonic stem cells. Nature. 2010; 463:237-240. [PubMed: 20075919]

138. Matsui T, Leung D, Miyashita H, Maksakova IA, Miyachi H, Kimura H, et al. Proviral silencing in embryonic stem cells requires the histone methyltransferase ESET. Nature. 2010; 464:927931. [PubMed: 20164836]

139. Fujita N, Watanabe S, Ichimura T, Tsuruzoe S, Shinkai Y, Tachibana M, et al. Methyl-CpG binding domain 1 (MBD1) interacts with the Suv39h1-HP1 heterochromatic complex for DNA methylation-based transcriptional repression. J Biol Chem. 2003; 278:24132-24138. [PubMed: 12711603]

140. Ohki I, Shimotake N, Fujita N, Jee J, Ikegami T, Nakao M, et al. Solution structure of the methylCpG binding domain of human MBD1 in complex with methylated DNA. Cell. 2001; 105:487497. [PubMed: 11371345]

141. Ho KL, McNae IW, Schmiedeberg L, Klose RJ, Bird AP, Walkinshaw MD. MeCP2 binding to DNA depends upon hydration at methyl-CpG. Mol Cell. 2008; 29:525-531. [PubMed: 18313390]

142. Clouaire T, de Las Heras JI, Merusi C, Stancheva I. Recruitment of MBD1 to target genes requires sequence-specific interaction of the MBD domain with methylated DNA. Nucleic Acids Res. 2010; 38:4620-4634. [PubMed: 20378711]

143. Walker JR, Avvakumov GV, Xue S, Li Y, Bountra C, Weigelt J, et al. Structure of the replication foci-targeting sequence of human DNA cytosine methyltransferase DNMT1. 2008 http:// www.rcsb.org/pdb/explore.do?structureid=3epz.

144. Rottach A, Frauer C, Pichler G, Bonapace IM, Spada F, Leonhardt H. The multi-domain protein Np95 connects DNA methylation and histone modification. Nucleic Acids Res. 2010; 38:17961804. [PubMed: 20026581]

145. Citterio E, Papait R, Nicassio F, Vecchi M, Gomiero P, Mantovani R, et al. Np95 is a histonebinding protein endowed with ubiquitin ligase activity. Mol Cell Biol. 2004; 24:2526-2535. [PubMed: 14993289]

146. Karagianni P, Amazit L, Qin J, Wong J. ICBP90, a novel methyl K9 H3 binding protein linking protein ubiquitination with heterochromatin formation. Mol Cell Biol. 2008; 28:705-717. [PubMed: 17967883]

147. Hashimoto H, Horton JR, Zhang X, Bostick M, Jacobsen SE, Cheng X. The SRA domain of UHRF1 flips 5-methylcytosine out of the DNA helix. Nature. 2008; 455:826-829. [PubMed: 18772888]

148. Arita K, Ariyoshi M, Tochio H, Nakamura Y, Shirakawa M. Recognition of hemi-methylated DNA by the SRA protein UHRF1 by a base-flipping mechanism. Nature. 2008; 455:818-821. [PubMed: 18772891]

149. Avvakumov GV, Walker JR, Xue S, Li Y, Duan S, Bronner C, et al. Structural basis for recognition of hemi-methylated DNA by the SRA domain of human UHRF1. Nature. 2008; 455:822-825. [PubMed: 18772889]

150. Hashimoto H, Vertino PM, Cheng X. Molecular coupling of DNA methylation and histone methylation. Epigenomics. 2010; 2:657-669. [PubMed: 21339843] 
A

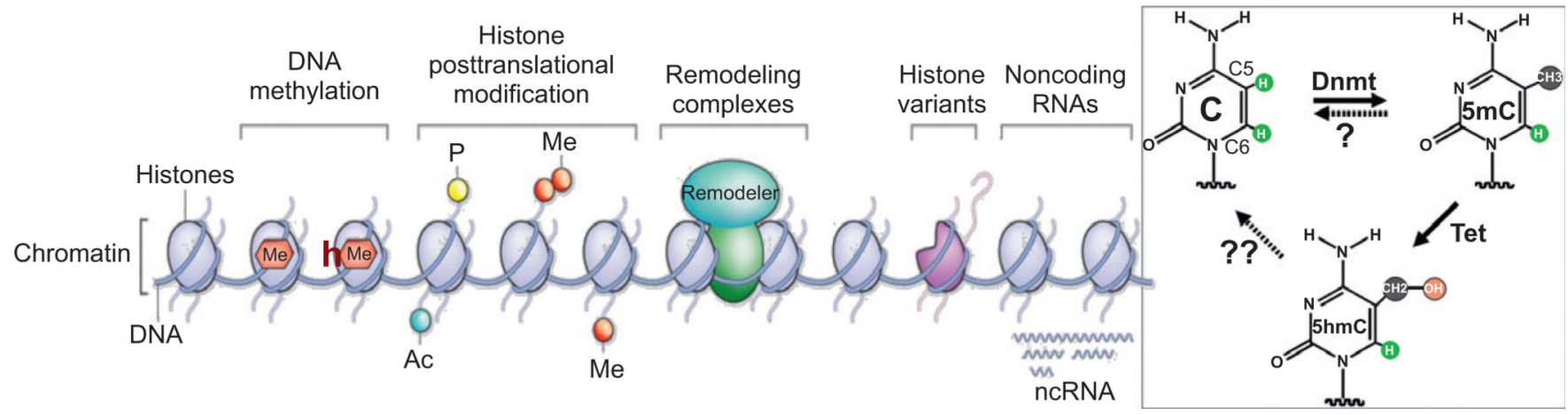

Fig. 1.

Possible components of an epigenetic "code." (A) Five broad and interrelated phenomena affect chromatin structure: DNA methylation, histone modification, chromatin-remodeling, histone replacement by variants, and the effects of noncoding RNAs. All five have been shown to be essential contributors to the epigenetics, though DNA methylation and histone modifications have, so far, been much more extensively investigated. Adopted and modified from Ref. 3. (B) DNA cytosine methylation, hydroxylation, and demethylation. The question mark indicates possible activity of DNA demethylases. ${ }^{4-9}$ "Tet" indicates conversion of $5 \mathrm{mC}$ to $5 \mathrm{hmC}$ in mammalian DNA, by the MLL fusion partner TET $1 .{ }^{10} \mathrm{It}$ is currently unknown whether $5 \mathrm{hmC}$ is an end product or an intermediate in active DNA demethylation. The double question mark indicates a possible MTase-assisted removal of the C5-bound hydroxymethyl group. ${ }^{11}$ 
A

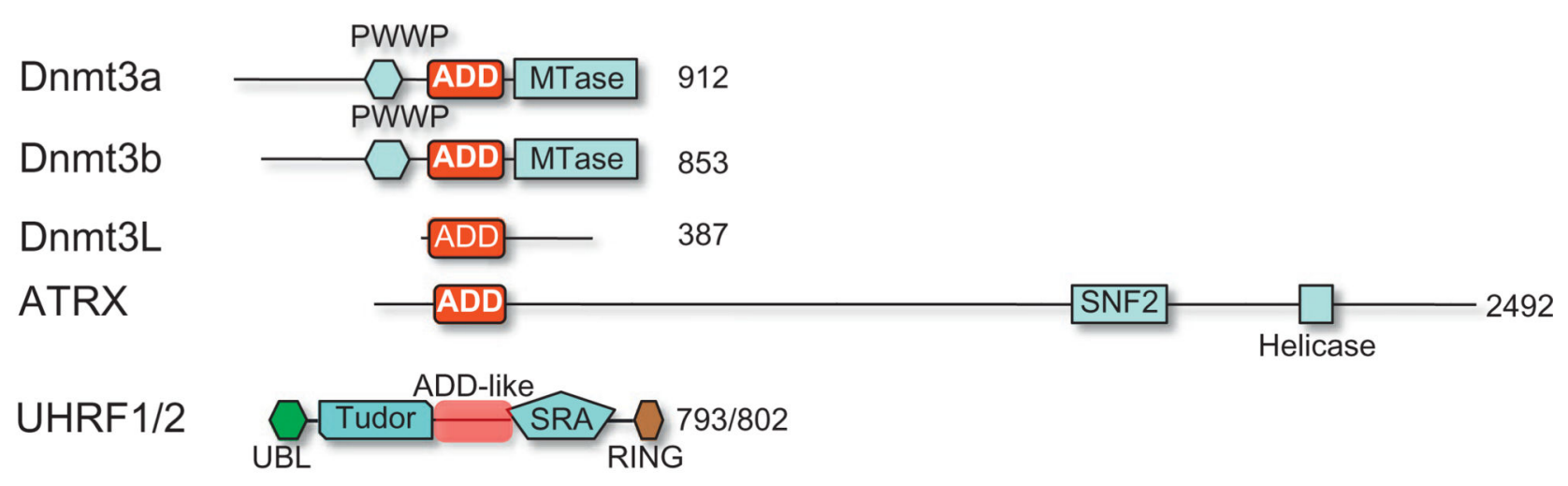

B

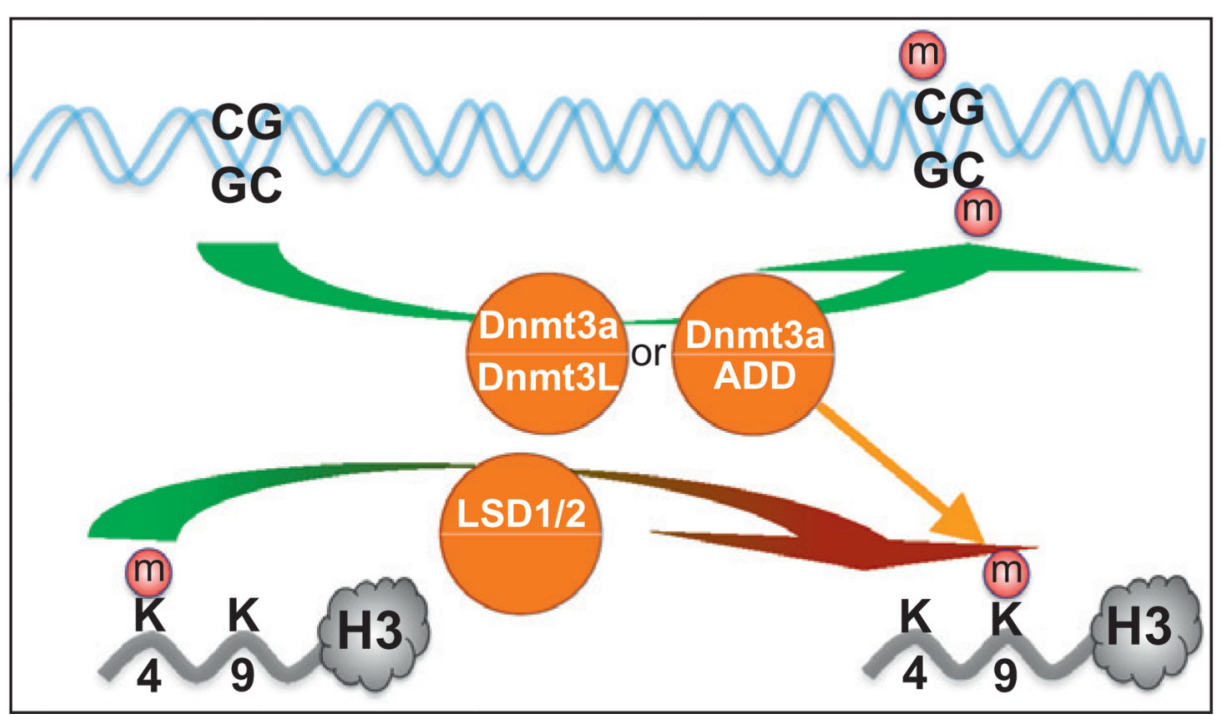

Fig. 2.

$\mathrm{H} 3 \mathrm{~K} 4 \mathrm{me} 0$ interacting proteins. (A) Domain architecture of $\mathrm{H} 3 \mathrm{~K} 4 \mathrm{me} 0$-interacting proteins containing ADD domains. ATRX interacts with histone H3.3, ${ }^{96,97}$ and mutating the K4 residue of H3.3 significantly diminishes ATRX-H3.3 interaction..$^{98}$ (B) Model of the reactions that regulate DNA methylation by Dnmt3a/3L. Recognition of H3K4me0 by the ADD domain of DNMT3 directs the DNA methylation reaction. The " $m$ " in a red circle indicates one or more methyl groups in DNA $(5 \mathrm{mC})$ or histone lysines $(\mathrm{Km})$. 


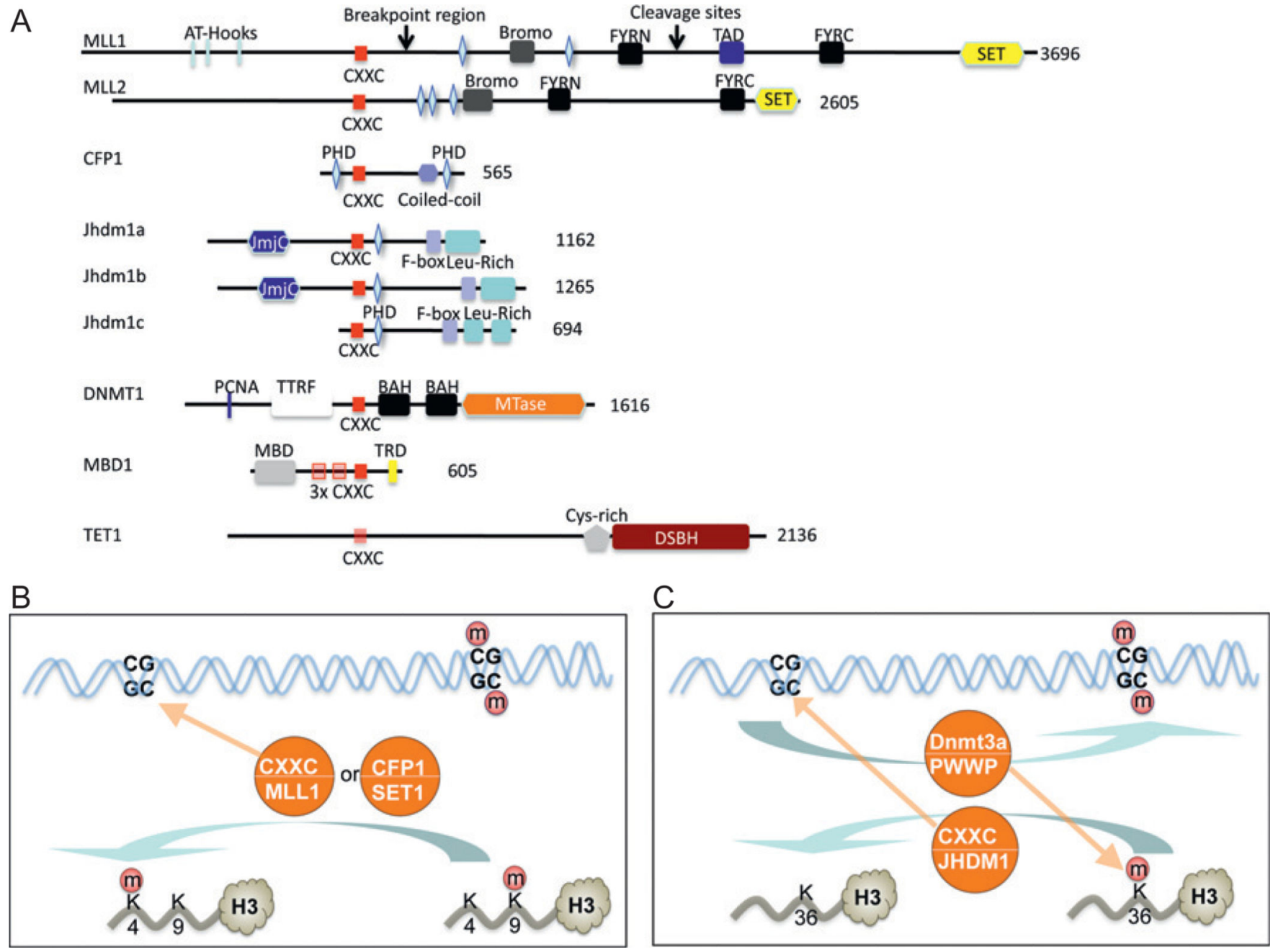

Fig. 3.

CpG interacting proteins (A) Domain architecture of proteins containing a CXXC domain (two copies of $\mathrm{CxxCxxC}$ motif). (B) Model of the H3K4 methylation reaction by MLL/ SET1 proteins. CXXC domain-mediated binding to unmethylated $\mathrm{CpGs}$ directs the methylation of H3K4 by MLL/SET1 proteins. 
A

$\mathrm{MeCP} 2$

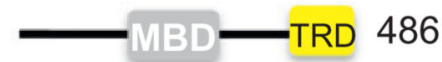

MBD1
MBD2
MBD3
MBD4

$3 \times$ CXXCTRD

VIBD- -7 - 605

SETDB1

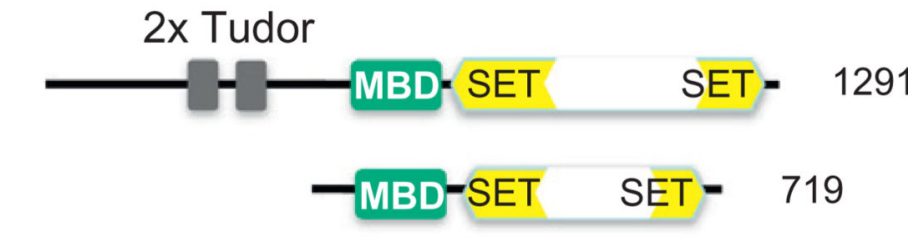

B

SETDB2

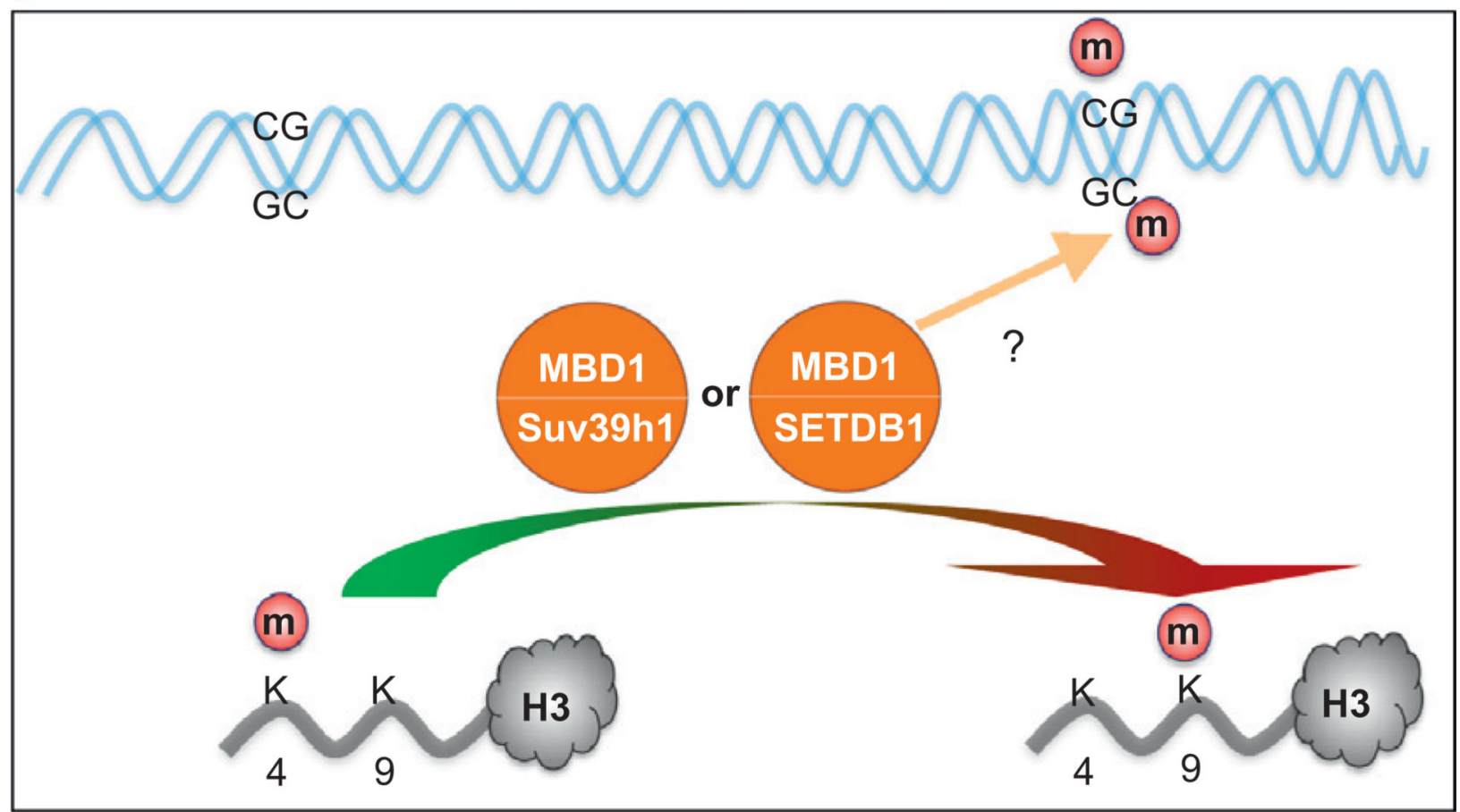

Fig. 4.

MBD containing proteins. (A) Domain architecture of known and putative proteins containing a MBD domain. (B) Model of the reactions that regulate $\mathrm{H} 3 \mathrm{~K} 9$ methylation by SUV39H1 or SETDB1. Recognition of methylated CpGs by the methyl-CpG domain of MBD1 directs methylation of H3K9me3. The "?" refers to the interactions need to be experimentally verified. 